\title{
軌道上組立作業ロボット 用エンドェフェクタの開発*1 Development of Space Robot End-Effecter for On-Orbit Assembly
}

\author{
西田 信一郎*2・吉 川 恒 夫*3
}

Shin-ichiro Nishida and Tsuneo YoshiKawa

Key Words : Space Robot, Assembly, End-Effecter, Force Control, Mechanism

\begin{abstract}
We are studying next generation space robot technology for on-orbit assembling of large space structure. A new space robot end-effecter suitable to on-orbit structure assembling was designed and its prototype model was developed and tested. This paper describes the required function, performance for space robot end-effecter, new mechanism design and testing results of prototype model.
\end{abstract}

\section{1. は じめに}

軌道上での大型構造物として, 宇宙ステーションの他に 大型宇宙望遠鏡, 宇宙電波望遠鏡, 太陽光発電衛星などが 検討されている1,2) . 打上機のフェアリングサイズによって 打上可能な機器サイズが限られるため, 大型構造物は展開 機構や軌道上での組立により構築する必要がある . 展開機 構では, 華奢でヒンジの多い構造が避けられないため, 構 造柔軟性やヒンジのガタが軌道上での形状精度や指向方向 制御性を確保する上で問題となるため, 高精度の構造物は 軌道上組立か想定される . 軌道上での組立作業においては 組立途中の構造物上をロボットが移動して広い作業領域を 確保して組立を行うことか効率的である ${ }^{3,4)}$. ロボットが構 造物上を移動するためには，電源・信号をロボットに供給 するためのラインやコネクタ付き取っ手などの機能要素を 組立構造物に付加し，エンドェフェクタはこれを把持しな がら移動する形態が必要であり, エンドェフェクタの把持 状態の保持性やコネクタ結合が重要な課題となる．特に軌 道上での構造物組立では, 移動用だけでなく各要素に取っ 手を設けてハンドリングや組立をするため, 取っ手の軽量 化も重要な課題となる . 宇宙ロボット用エンドェフェクタ としては, シャトルマニピュレータ (SRMS) やマニピュ レータ飛行実験 $(\mathrm{MFD})^{5)}$, 技術試験衛星 VII 型のロボット の事例がある ${ }^{6,7)}$. しかし，これらの事例ではガイド構造や コネクタ結合機能が取っ手の側にあり取っ手の重量が嵩む こと，把持状態での保持力を駆動機構のブレーキ力や軸受 の耐荷重性に依存し，保持力を高く設定できないこと，等 の課題があった．筆者らは，これらの課題を踏まえて，各 研究部隊と協力して軌道上でのロボットによる組立作業や 組立構造について研究を行い試作・評価を行ってきた8 10).

\footnotetext{
*1 (C) 2005 日本航空宇宙学会

平成 16 年 7 月 15 日原稿受理

*2 宇宙航空研究開発機構

*3 京都大学大学院
}

本論文では, 軌道上での構造物組立作業および構造物上 の自立的移動に対応したエンドェフェクタへの要求機能お よび要求性能を検討し, 従来例における前述の課題をクリ アし, 要求を満足する方式として, 機構の非バックドライ ブ性による保持に着目して, 新規方式であるクリップ式機 構および挿入・嵌合のための球面形状ガイドと円弧形状エッ ジのカップ型取っ手を考案した . さらに , これらの方式を適 用した高い保持性能と挿入性, 電気コネクタ結合機構, 軽 量な取っ手を実現するエンドェフェクタの構成を検討・試 作し, 試験・評価により所期の特性を確認した結果につき 記述する .

\section{2. 軌道上組立作業とエンドエフェクタ要求事項検討}

2.1 組立作業概念 宇宙ロボットによる大型構造物組立 作業の概念図を第 1 図に示す . ロボットアームは, 構造要素 を順次結合することにより組立作業を行う . 組立作業の進 行に伴い作業場所の変更が必要になるが, ロボットアーム は構造物上を尺取り虫のように移動して作業場所を変更す る.この方式は, 国際宇宙ステーション (ISS) のマニピュ レータ (SSRMS) にも適用された方式である．

2.2 組立作業用ロボットアーム 構造部材のサイズと して一般的なロケットのフェアリング内径に整合する直径 $3 \mathrm{~m}$ 程度を想定すると，特異姿勢を回避しつつ，これを無 理なく扱って組立作業を行うアームとしては，長さに概ね 数 $10 \%$ 余裕が必要であり， $4 \mathrm{~m}$ 以上の長さが必要となる . そこで, 組立作業のロボットアームとして, 第 2 図に示す 構成を想定する。

2.3 組立作業項目 宇宙ロボットによる軌道上組立作業 は, 主に第 1 表に示す作業項目で構成される . 各作業項目 に必要なロボットアームのエンドェフェクタの機能要素を 第 1 表に併せて示す . 把持作業には ，画像計測を伴う.ま た, 信号伝送を必要とするのは, 尺取り虫型の移動と取付 確認や状態の確認である. いずれの作業においても取っ手 以外のものの把持の必要性は見当たらない . MLI の着脱の 


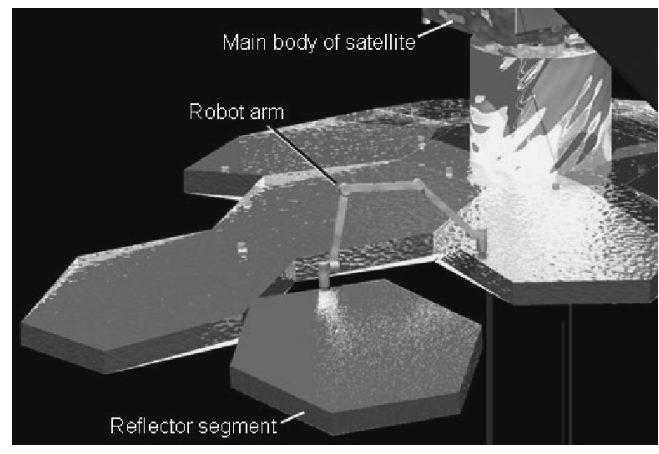

第1図＼cjkstart宇宙ロボットによる軌道上組立の概念図

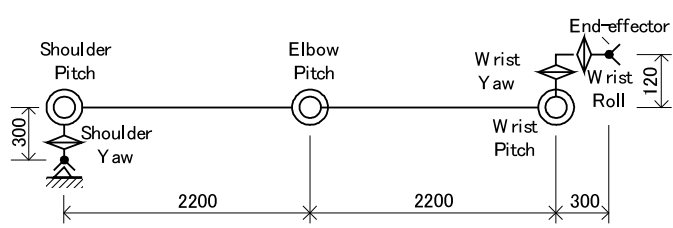

第 2 图 想定するロボットアームの自由度配置

第 1 表＼cjkstart組立作業に必要なエンドエフェクタ機能要素

\begin{tabular}{lccc}
\hline \multicolumn{1}{c}{ Tasks } & Grasp & Signal transmit & Torque apply \\
\hline Payload handling & $\bigcirc$ & & \\
Attach a segment & & $\bigcirc$ & $\bigcirc$ \\
Take out a segment & $\bigcirc$ & & \\
Inchworm motion & $\bigcirc$ & $\bigcirc$ & \\
Attach/detach MLI & $\bigcirc$ & & \\
Confirm connection & $\bigcirc$ & $\bigcirc$ & $\bigcirc$ \\
\hline
\end{tabular}

ように軽量で一端が連結された対象を扱う場合のために電 気コネクタを持たない小型の取っ手も有効である．

2.4 エンドェフェクタ要求機能・性能 軌道上組立への 対応から，エンドェフェクタには，次の機能を具備するこ とが有効かつ必要である。

a. 把持機能 : 位置ずれのある状態でも着実に把持

b. ソケットレンチ機能：トルク印加・回転駆動機能

c. 電気コネクタ結合 : 電源や信号の授受

d. 軽量な取っ手 : シンプル・軽量な取っ手の把持

構造物上をロボットアームガ移動するため, ロボットアー ムが移動に際して把持する取っ手部やエンドエフェクタは， ロボットアームで発生する最大荷重が加わることを想定し て構成する必要がある.また, 移動式アームのエンドエフェ クタは, 肩関節の関節出カトルクレベルのモーメントに対 する保持耐性が必要である. 先端力 $10 \mathrm{~N}$ の第 2 図の自由 度配置のアームの場合, 関節所要出カトルクは約 $50 \mathrm{Nm}$ と なる.最大発生荷重は, アームの姿勢と周辺条件に左右さ れるが，先端力仕樣值の 30 倍の $300 \mathrm{~N}$ の耐性を確保する . 設定したエンドエフェクタの要求性能を第 2 表に示す.

\section{3. 組立作業用エンドェフェクタの方式検討}

3.1 従来のエンドェフェクタの課題 SRMS のスネヤ ワイヤ方式や技術試験衛星 VII ロボットのリンク指方式な どの従来のエンドェフェクタは , 結合状態の保持を駆動機
第 2 表 エンドェフェクタの要求性能

\begin{tabular}{lcl}
\hline \multicolumn{1}{c}{ Items } & Performance & \multicolumn{1}{c}{ Remarks } \\
\hline Pull-in force & $60 \mathrm{~N}, 3 \mathrm{Nm}$ & by fingers \\
Allowable load & $300 \mathrm{~N}, 50 \mathrm{Nm}$ & in holding \\
Allowable misalignment & $10 \mathrm{~mm}, 3 \mathrm{deg}$ & combined \\
Electric connector & D-sub: $15 \mathrm{pins} \times 2$ & power, signal \\
Socket driver torque & $20 \mathrm{Nm}$ & \\
\hline
\end{tabular}

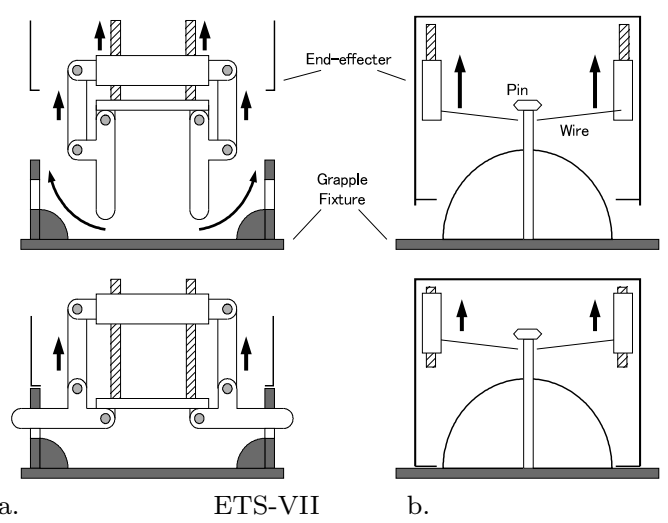

第3図＼cjkstart従来のエンドェフェクタの把持方式

構のブレーキにより実現しており，ブレーキカを上回る外 カが加わつた場合には, 駆動機構がバックドライブされて 把持状態が維持できない方式であった (第 3 図).このた め, 確実な保持のためには, JEMRMS 子アームのように ラッチ機構を別途追加する必要があった . また, 挿入のガ イドが，主に取っ手側に設けられ，取っ手の重量が嵩む問 題があった .また, 電気コネクタの結合は, 取っ手側にコ ネクタの前後動作の機構を設ける方式であったため, 取っ 手の重量が嵩み, ソケットレンチ機能を占有してしまう問 題があった .

3.2 新規エンドエフェクタ方式 把持物の不慮の放出が 甚大な被害を招く部材の搬送やロボットアームの移動時の 基部固定には把持の着実性が要求される．また，前述のよ うに取っ手以外の対象の把持の必要性はない，光こで，専 用の取っ手を着実に把持できる結合機構方式を選定し，前 述の組立作業用エンドエフェクタ要求機能に対応した検討 を行い,エンドェフェクタとして，以下の各種の特徴を持っ た構成を新規に考案した。

a. 挿入性の良い半球形ガイド構造をエンドエフェクタ側に

有する (取っ手側にガイド構造不要)

b. クリップ式把持による高剛性，高耐荷重保持

c. クリップ指駆動機構連動のコネクタ結合機構

取っ手側にガイド構造やコネクタ結合機構が不要となるた め，取っ手の構成をシンプルにでき，軽量化できる．半球 形ガイド構造を有するエンドェフェクタの取っ手への挿入 概念とクリップ式把持の概念を第 4 图に示す .

3.3 球形ガイド構造による㨂入 作業対象の機器に対 する構成上の負担軽減/トータル重量軽減の観点から, 取っ 手を極力軽量化することが望ましい，光こで，次の観点か ら,球形ガイドをエンドエフェクタ側に設け, 取っ手をカッ 


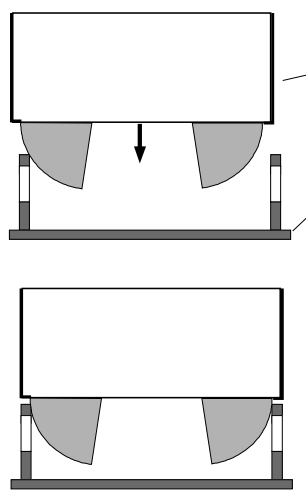

a. 球形ガイドによる挿入

第4图 球形ガイド挿入とクリップ式把持方式

プ型として構成を極カシンプルにする．

・広い挿入許容位置ずれ範囲

·挿入後の高い保持性

取っ手への挿入の抵抗となるのは，ガイド構造と取っ手 の摩擦である . 接触面法線の挿入方向に対する傾斜角が $\theta$ のガイド構造では, 挿入力 $f_{\mathrm{v}}$ のエンドエフェクタに加わ る摩擦力は次式で求められる.

$$
f_{\mathrm{d}}=f_{\mathrm{v}} \cdot \mu \cdot \cos \theta+f_{\mathrm{ds}}
$$

ここで， $\mu:$ 摩擦係数

$$
f_{\mathrm{ds}}: \text { 静止状態での最大摩擦増加分 }
$$

従って, ガイド構造の接触面法線は，挿入方向に対して一定 以上の角度を確保しないと插入が進行しない．本エンドェ フェクタの使用環境として想定する常温の真空中では, 宇 宙用固体潤滑剂として広く使われている二硫化モリブデン 焼成膜の摩擦係数は 0.03 程度である ${ }^{11)}$. 乥こで，二れに対 して 3 倍の余裕を確保し, 静止状態の摩擦増加分として, クーロン摩擦の 2 倍を想定すると, 次式が接触面の傾斜角 の条件となる。

$$
\theta \geq \tan ^{-1}(3 \mu)
$$

従って, 接触面の傾斜角は, 約 15 度以上必要である。

一方，把持後に横荷重や捻り卜ルクに対する高い保持性 を確保する観点から嵌合部の傾斜角を大きくする必要があ る. 挿入ガイド面から嵌合面へ滑らかに移行するガイド構 造として球面形状を基本としたガイド形状とカップ型取っ 手の円弧形状のエッジを考案した . 単に 1 つの半球状のガ イドでは，中心軸に対して回転対称であるため，嵌合後に ロール軸回転（捻り）に対する保持ができない，乥こで，半 球を 2 分割して中心から離した配置にし, 捻りに対する保 持性を確保する. 円弧形状の取っ手エッジと球面形状 (半 径 : $R$ ) ガイドの接触面の挿入方向に対する傾斜角 $\theta$ は次 式で求められる .

$$
\theta=\sin ^{-1}\left(\frac{R-\sqrt{\varepsilon_{x}^{2}+\varepsilon_{y}^{2}}}{R}\right)
$$

ここで, $\varepsilon_{x}, \varepsilon_{y}:$ エンドェフェクタ横位置ずれ

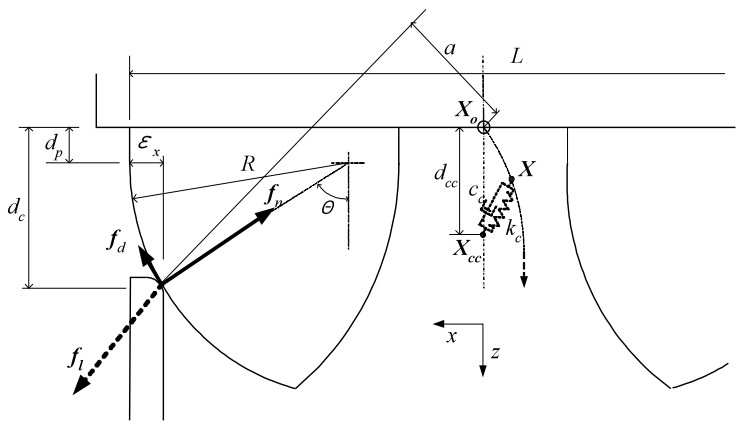

第5图 球形ガイド挿入時の発生荷重関係

上記の検討により傾斜角 $\theta$ が 15 度以上あれば, 十分に挿 入が進行する.従って, 式 (3)より次式が導かれる.

$$
\sqrt{\varepsilon_{x}^{2}+\varepsilon_{y}^{2}} \leq\left(1-\sin 15^{\circ}\right) R
$$

即ち, ガイド構造の球面半径の約 0.74 倍以下の横位置ずれ であれば，押し付け・従動により挿入が進行する．

位置ずれ状態からのガイドに沿った従動動作では，ロボッ トアームにカ覚センサ情報フィードバックによる仮想イン ピーダンス制御を適用する ${ }^{12 \sim 14)}$. 以下では，仮想インピー ダンス制御状態での球面形状ガイドの取っ手への挿入につ いて検討する . 簡単のため,$x$ 方向のみの位置ずれがある 状態での㨂入状況を第 5 图に示す .

ロボットアームの先端位置の参照点をエンドエフェクタ の前面中央に置き，この位置を $\boldsymbol{X}$ とする（初期接触時の 位置 : $\left.\boldsymbol{X}_{\mathrm{o}}\right)$. 嵌合のための平行挿入部の厚みを $d_{\mathrm{p}}$ とする とガイド構造と取っ手のエッジの接触位置の $\boldsymbol{X}$ からの挿 入方向深さ $d_{\mathrm{c}}$ は, 次式で求められる.

$$
d_{\mathrm{c}}=R \cdot \cos \theta+d_{\mathrm{p}}
$$

接触点には, 挿入動作によるアーム先端力 $f_{1}$ に対して抗力 $f_{\mathrm{n}}$ ，摩擦力 $f_{\mathrm{d}}$ が生じる. 挿入力 $f_{1}$ の接触面接線方向成分 $f_{\mathrm{lc}}$ が摩擦力 $f_{\mathrm{d}}$ を超えるまでは挿入が進行しない，仮想イ ンピーダンス制御のコンプライアンス中心 $\boldsymbol{X}_{\mathrm{cc}}$ をロボット アームの指令位置 $\boldsymbol{X}_{\mathrm{com}}$ と同じ位置に置くと，接触後もコ ンプライアンス中心 $\boldsymbol{X}_{\mathrm{cc}}$ は指令された挿入速度で進行し， コンプライアンス中心 $\boldsymbol{X}_{\mathrm{cc}}$ と仮想インピーダンス制御で生 成される目標位置 $\boldsymbol{X}_{\mathrm{ref}}$ に偏差 (仮想変位) を生じる.こ れに対応して仮想インピーダンス制御によりアーム先端力 $f_{1}$ を生じ，接触面接線方向成分 $f_{\mathrm{lc}}$ が摩擦力 $f_{\mathrm{d}}$ を超えた 時点から挿入か淮行する. 静的な動作を想定し, 慣性力分 を無視すれば，アーム先端力 $f_{1}$ は，次式となる．

$$
\boldsymbol{f}_{\mathrm{l}}=\boldsymbol{k}_{\mathrm{c}}\left(\boldsymbol{X}_{\mathrm{ref}}-\boldsymbol{X}_{\mathrm{cc}}\right)+\boldsymbol{c}_{\mathrm{c}}\left(\dot{\boldsymbol{X}}_{\mathrm{ref}}-\dot{\boldsymbol{X}}_{\mathrm{cc}}\right)
$$

現在位置 $\boldsymbol{X}$ は，制御の仮想インピーダンス制御による 目標位置 $\boldsymbol{X}_{\mathrm{ref}}$ に対して微小な位置制御偏差分だけずれた 位置にある.現在位置はガイドに沿った従動により物理的 に拘束された球面上を移動し，挿入が進行する．なお，目 標位置 $\boldsymbol{X}_{\mathrm{ref}}$ はアーム構造弾性やサーボ弾性分だけコンプ ライアンス中心 $\boldsymbol{X}_{\mathrm{cc}}$ 側に少し食い込んだ軌道を通る。 
接触点の抗力 $f_{\mathrm{n}}$, 摩擦力 $f_{\mathrm{d}}$ の合力ベクトルは, ロボッ トアームの先端位置の参照点 $X$ を通らず，例えば第 5 図 では必ず参照点 $X$ の左側を通る .これにより $-a f_{1}$ の倒 れのトルクを生じるが, 図の右回り方向のトルクであるた め, エンドェフェクタの胴部の前面が取っ手に接触した時 点で打ち消すトルクが作用して姿勢が修正される.球形状 のガイド構造では基本的にガジリを生じないが, 平行挿入 部は対角線が最大長径となり，唯一ガジリを生じる可能性 がある. しかし, ガイド構造の長径 $L$ と取っ手の長径 $L_{\mathrm{G}}$ に次の差異 (クリアランス $l_{\mathrm{c}}$ ) を設ければ，ガジリを生じ ることなく挿入・嵌合が行われる.

$$
l_{\mathrm{c}}=\sqrt{L^{2}+d_{\mathrm{p}}^{2}}-L
$$

平行挿入部 (長さ $d_{\mathrm{p}}$ ) は, 嵌合後の横荷重や捻りトルク に対する接触面圧の低減のためには有効であるが，挿入性 の観点からは必要ないことが判る .

以上のように，球面形状を基本としたガイド構造を用い， 仮想インピーダンス制御での挿入を行うことにより，位置・ 姿勢ずれが修正されて嵌合位置に至ることができる．

3.4 クリップ式把持機構による把持/保持 エンドエフェ クタの高い負荷モーメントに対して耐性と剛性を確保する ため, 新規の把持機構方式としてクリップ式を提案する .こ の方式は，指動作によりエンドエフェクタの構造と取っ手 構造の双方を指構造で挟み込むことにより保持を実現する 方式であり，次の特徵を有する .

a. 保持状態でのロードパスが構造だけを通り，構成上で高 い耐性の確保か灘しい指の支持部や駆動機構を通らない ため，保持而性が高い .

b. 構造どうしの接触面を広くとれ，構造接触であるためガ タが小さく剛性が高い.

概して円柱外形のエンドェフェクタと取っ手の結合状態 での保持において, 以下に示す配分方式で各方向の印加外 カ/トルクに対する保持性/而性を確保する.

(1) 横方向並進力 : 球形ガイド構造の剪断耐性

(2) 押し付け並進力 : 前面構造圧縮而性

(3) 引つ張り並進力 : 指機構引つ張り耐性

(4) 捻りトルク : 球形ガイド構造の中心軸回り剪断而性

(5) 倒れトルク : 指機構引つ張り耐性

本方式での指機構による保持/而性の概念を従来方式例 (ETS-VII ロボットの把持機構) と比較して第 6 図に示す. 従来の方式では指の支持点や駆動するリンク機構のヒンジ 部に印加荷重 $F$ や乥れを上回る荷重 $F 1, F 2$ が発生し， $F 2$ がアクチュエータの負荷荷重となるが, クリップ式の 機構ではロードパスカ指の構造部材上に限られる. 支点や ローラでの荷重 $F 4$ はクリップの接触面の印加荷重に対す る傾斜角に依存するが，例えば傾斜角を 3 度とすれば $F 4$ は印加荷重の約 $5.2 \%$ に過ぎない，また，結合状態を保持す るためには, 従来の方式では, 指の駆動アクチュエータに 駆動方向の予圧をかけた状態でサーボ保持するかまたはブ レーキ保持する必要があった .一方, クリップ式では指駆 動のローラの動作方向と指の動作方向が直交しており駆動

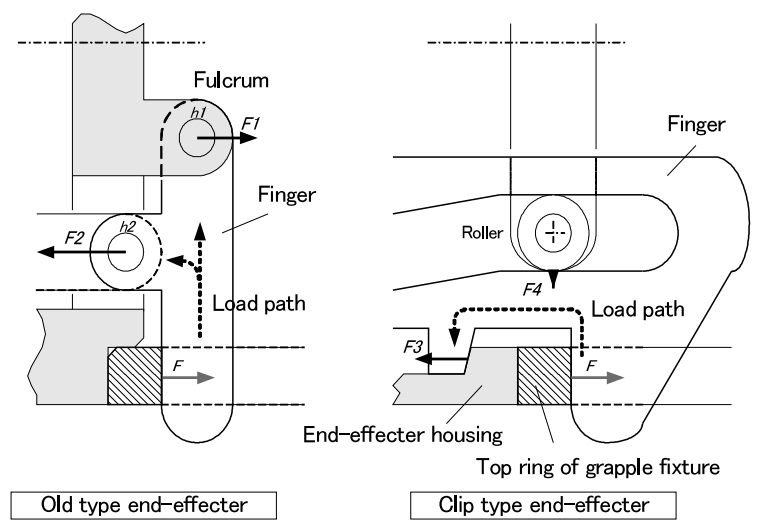

第 6 図 クリップ式把持機構での荷重関係

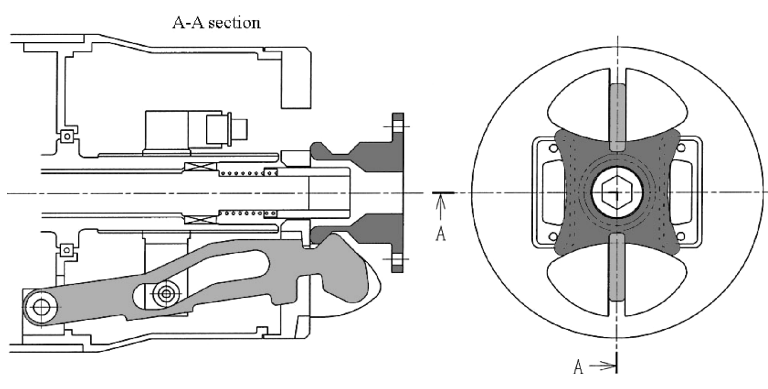

第 7 図 小取っ手の把持形態

機構アクチュエータがバックドライブされないため, アク チュエータにはブレーキは不要であり, 機構の内部摩擦だ けで保持が可能である . 従って, 結合状態の保持のための アクチュエータの荷重負担は無い，なお，小取っ手の把持 も指の内側によるクリップ式把持とし, ローラを逆方向に 駆動することにより実現できる (第 7 図) .

3.5 コネクタ結合機構 クリップ動作をする指の駆動 機構を前後直進カム方式とすることにより，電気コネクタ の結合機能を兼ね備えた構成を考案した．電気コネクタの 嵌合のための許容位置ずれ量は, 僅か (例えば, D-sub コ ネクタで $0.5 \mathrm{~mm}$ 以下) であるため，指による取っ手の引 き込み・嵌合が完了した後にコネクタ結合が行われる構成 とした . 即ち , 指の把持完了後にローラ機構がさらに前進 し，指の角度を維持したままでローラ機構と同じムービン グピース上に取り付けられたコネクタが直進・結合するカ ム機構とした (第 8 図).

\section{4. エンドェフェクタの試作}

4.1 ガイド構造 ガイド構造面には, 二硫化モリブデ ン焼成膜による固体潤滑を施すことを基本とする . 平行挿 入部の長さを $5 \mathrm{~mm}$ とし, 大・小取っ手に対応する球形ガ イド構造の半径は各々 $30 \mathrm{~mm}, 23 \mathrm{~mm}$ に設定した .

4.2 大取っ手 電気コネクタを有し, 構造物上での伝い 歩きや構造要素のハンドリングに用いる大取っ手 (L-GRIP) は, 組立構造物上に多数必要であるため, 極力軽量にする 必要がある. 弚こで, エンドエフェクタの二分割配置した 

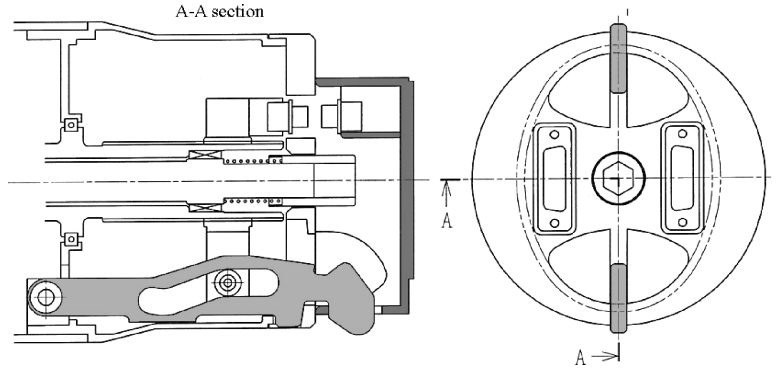

a. Grasping of the large grapple fixture
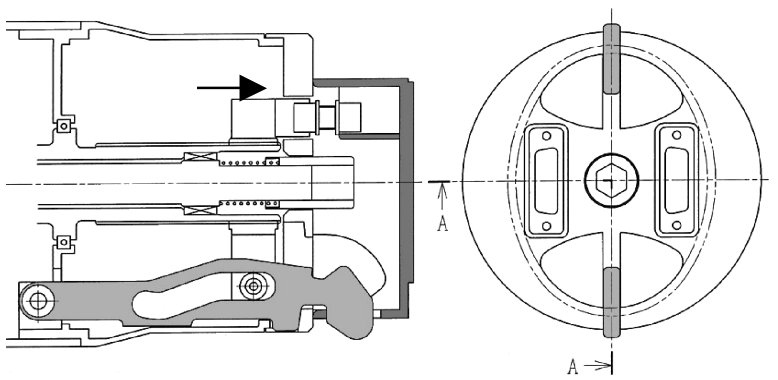

b. Mating of electrical connector

第 8 図 大取っ手把持の詳細形態とコネクタの結合

球面形状のガイド構造に嵌合するように複数の円弧の連続 で構成された（全体としては楕円形状に近い）カップ型の シンプルで軽量な構造を考案した，半球を分割したガイド 構造と干渉しない位置に 1 対の D-sub コネクタを配置し た 、材質は, アルミ合金を基本とし，カップの内面および エッジはエンドェフェクタのガイド構造と摺動を生じるた め二硫化モリブデン焼成膜による固体潤滑を施すことを基 本とする ${ }^{11}$.

4.3 小取っ手 電気コネクタを持たない小取っ手は, 操 作時に大きな倒れモーメントが加わらないため, 軽量・小 型に構成できる. 弚こで, 半球を分割した形状のガイド構 造の内側にも球形のガイド形状を設け，ここに嵌合する円 弧形状部を有する (全体としては X 字型) の小型の取っ手 (S-GRIP) を考案した .把持姿勢の制約を緩和するために， 90 度ごとに対称な形状とした .中央には, ソケットドライ バに対応した穴を設ける.円弧型構造部は，ガイド構造や クリップ指との摺動を生じるため二硫化モリブデン焼成膜 による固体潤滑を施す。

各取っ手の試作機を第 9 図に示す . 大 , 小取っ手の重量 は, 各々 $170 \mathrm{~g}, 80 \mathrm{~g}$ であり, 大取っ手は例えば ETS-VII ロボット用の取っ手 $(1.6 \mathrm{~kg})$ と比較すると約 $1 / 10$ の重量 の軽量な構成となっている.

\section{4 クリップ指機構}

4.4.1 指形状 挿入が完全でなく，僅かに浮いた状態で も引き込んで把持・固定ができるようにクリップ指には， テーパ形状による引き込み導入部を設ける.

4.4 .2 材質 小さな構造に大きな荷重の加わる指機構に は, 鋼などの強度の大きく固体潤滑処理が可能な材質を用 いる必要がある.試作機は大気中用であるため，ステンレ ス鋼 (厚み：6 $\mathrm{mm}$ ) で構成した。

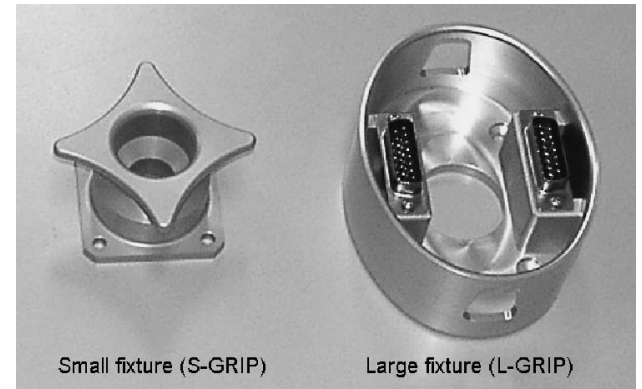

第 9 図 エンドェフェクタ用各種取っ手の試作品

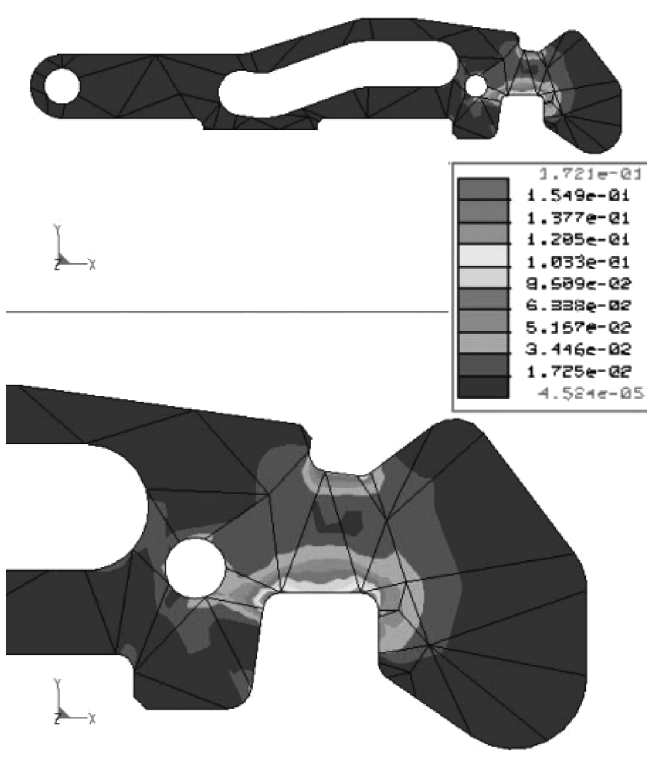

第 10 図 クリップ式把持機構の静荷重応力解析結果

4.4.3 解析 前述のように結合状態での保持においては, 指機構の引つ張り荷重耐性が重要となる. 例えば, 構造物 のアームの移動や把持物の搬送，固定作業などでは，何ら かの不具合で緊急停止をした場合などに慣性力によってロ ボットアームの基部となる取っ手に大きな荷重が加わる場 合がある .このような状態で指機構およびエンドェフェク 夕, 取っ手構造に加わる荷重を把持状態の指と周辺の構造 について有限要素法 (要素数：68) により解析した。解析 結果を第 10 图に示す.解析は $1 \mathrm{~N}$ の引つ張り荷重を取っ 手に加えた場合の結果である. 要求仕樣の $300 \mathrm{~N}$ が加わっ

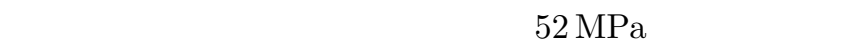
(ステンレス鋼) の降伏応力 $(1020 \mathrm{MPa})$ に対して十分に 余裕のある結果 (MS: 18.6) となった. 即ち, 指構造が保 持に影響する引つ張り荷重に対しては，(2 本の指で保持す るため) 要求仕樣 $300 \mathrm{~N}$ の 37.2 倍の荷重 $\left(1.12 \times 10^{4} \mathrm{~N}\right)$ までの耐性を確保でき, 倒れトルク要求仕樣 $50 \mathrm{Nm}$ に対し ては (取っ手の長径が $0.1 \mathrm{~m}$ であるため) 11.2 倍のトルク $\left(1.12 \times 10^{3} \mathrm{Nm}\right)$ までの耐性を確保できるという結果となっ た .これは, 例えば, 従来例の ETS-VII のエンドェフェク 夕（各々，約 $45 \mathrm{~N}, 5 \mathrm{Nm}$ ) の約 230 倍の耐性である.ま た，指の接触点の变位は約 $1.43 \times 10^{-8} \mathrm{~m}$ であり，引つ張り 岡性は約 $1.4 \times 10^{8} \mathrm{~N} / \mathrm{m}$ ，倒れ岡性は約 $7.0 \times 10^{5} \mathrm{Nm} / \mathrm{rad}$ 

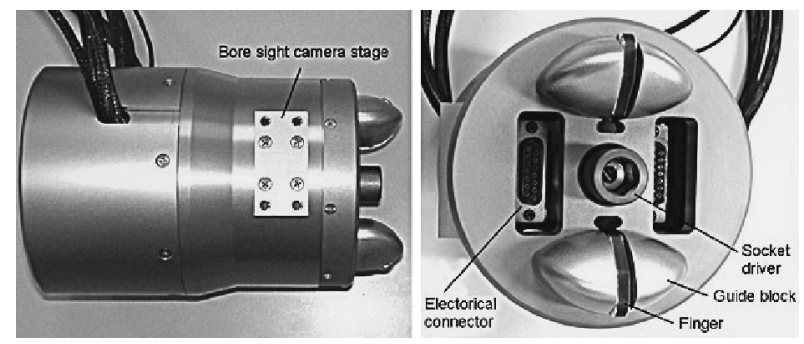

第11図 エンドェフェクタ試作機の外観

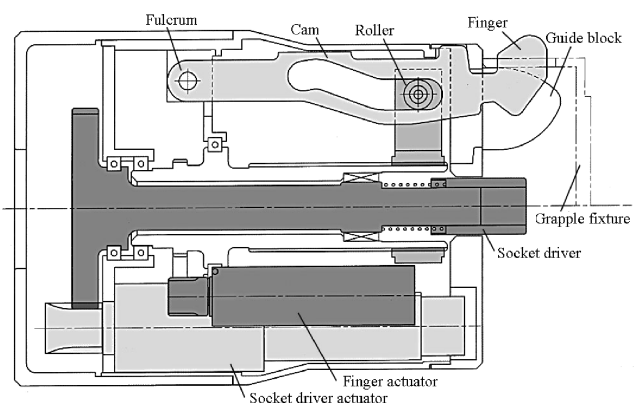

第 12 図 エンドエフェクタ内部の機構構成概要

と求められた . これは，想定するロボットアーム関節機構 の剛性 $\left(2.2 \times 10^{4} \mathrm{Nm} / \mathrm{rad}\right)^{13)}$ の約 32 倍である . 従って， 本解析結果から十分に高い保持耐性と剛性が得られること が確認できたと言える .

4.5 電気コネクタ 宇宙用機器には, 接触面に金メッキ が施された D-sub コネクタが多用されているが，これは展 性の高い金属である金による真空潤滑性を有し，軌道上で の着脱実験も実施されている15) . また , アライメントずれ の修正/吸収のために $0.5 \mathrm{~mm}$ ストロークの弾性部材をコネ クタの支持部に介在させた .

エンドェフェクタの試作機の外観を第 11 図に示し, 内部 の機構構成の概要を第 12 图に示す.

4.6 ソケットドライバ 六角形状のボルトヘッドに嵌合 して回転駆動をするソケットドライバを中央部に配置した 。 ソケットドライバには，指の駆動とは別のアクチュエータ (DC モータ, ハーモニックドライブ減速機) を設けること により，常に回転角度情報を保存できる．また，ソケット 部には，スプリングによる押し付け機構を内蔵している。

\section{5. 試験}

試作したエンドエフェクタが挿入性 , 保持性等の主要な 機能・性能要求を満足することを試験により確認した .

\section{1 挿入性試験}

5.1 .1 試験方法 大小の取っ手に対するエンドエフェク タの挿入の許容位置ずれ性能の試験を実施した . 取っ手とエ ンドェフェクタの横方向の相対的な位置ずれを微動ステー ジにより設定し，横方向および捻れ回転のコンプライアン ス機構で支持した取っ手に重力補償装置で吊り下げたエン ドエフェクタを残留重力で静的に挿入 (挿入力 : $18 \mathrm{~N}$ ) し， 挿入性を調ベた . コンプライアンス機構は, フリーボール
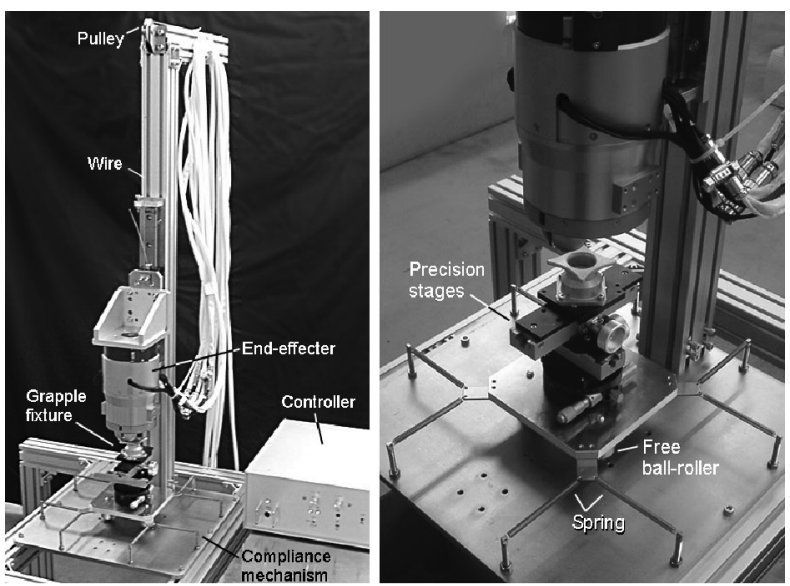

第 13 図＼cjkstart挿入性試験のコンフィギュレーション

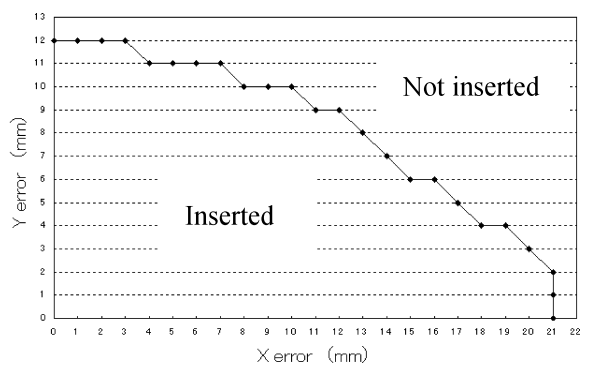

a. L-GRIP translational error case

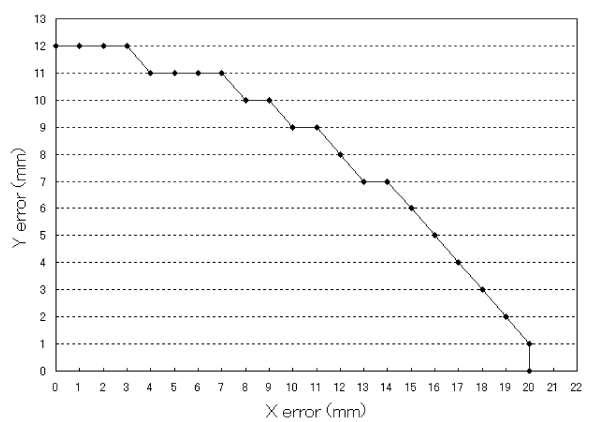

b. L-GRIP translational and rotational (3 deg) error case

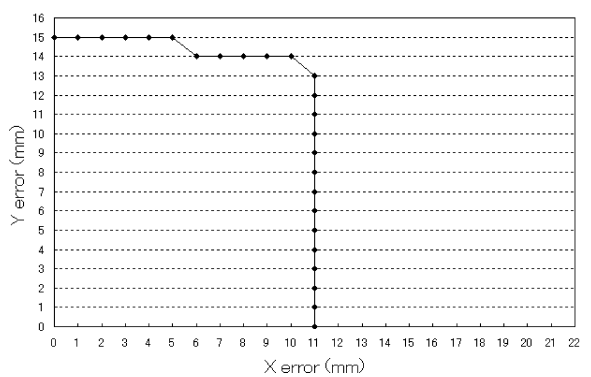

c. S-GRIP translational error case

第14図挿入性試験の結果（位置ずれと挿入可否）

ローラ機構で支持して水平方向に自在にしたステージ部に スプリングを接続 (並進岡性: $400 \mathrm{~N} / \mathrm{m}$, 回転岡性 : $20 \mathrm{Nm}$ ) する方式で構成した . 試験装置の構成を第 13 図に示す.

5.1 .2 試験結果 大,小の取っ手についての試験結果を 第 14 図に示す.いずれの取っ手についても $10 \mathrm{~mm}$ 以上の 許容位置ずれに対して挿入性が確保されていることが確認 


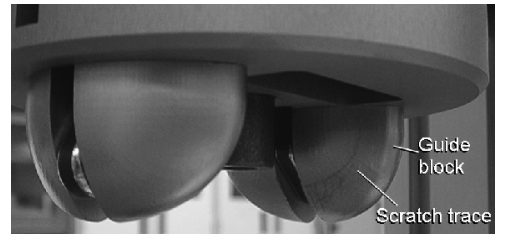

第 15 図 ガイド構造上の S-GRIP との接触痕

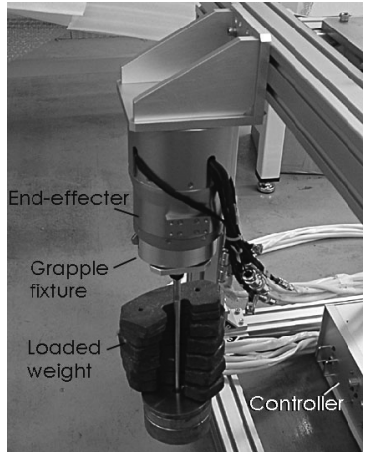

第16図引き込み試験のコンフィギュレーション

できた . また，小取っ手については，取っ手側の円弧形状 の端 (X 字の各先端) が制約となっており，ガイド上の接 触部の傾斜方向か挿入方向に直角になるケースが挿入の限 界の要因となっていることが判明した . 第 15 図にガイド構 造との接触痕を示す.従って, 90 度ごとの対称形状を見直 して 180 度対称としてX 字型の嵌合形状を長くすれば，挿 入の許容位置ずれ量をさらに大きくできることが判った .

\section{2 引き込み試験}

5.2 .1 試験方法 大取っ手に引っ張り荷重 $(100 \mathrm{~N})$ を印 加した状態で指による引き込み動作を行い，正常に引き込 み・嵌合が行えるかどうかを試験した、荷重は, 大取っ手 に錘を吊り下げて実現した . 引き込み試験のコンフィギュ レーションを第 16 図に示す.

5.2.2 試験結果 要求仕樣值 $(60 \mathrm{~N})$ を上回る $100 \mathrm{~N}$ の 印加荷重化でも問題なく引き込み動作ができ，正常に嵌合 された .これにより構成した指機構で引き込み機能が機能 し, 要求仕樣以上の性能が得られることか確認できた .

\section{3 保持性試験}

5.3.1 試験方法 取っ手を把持した状態での倒れモーメ ントに対する而性試験を実施した . 試験装置およびコンフィ ギュレーションを第 17 図に示す . 大取っ手を把持した状態 のエンドェフェクタにブームを取り付け，このブームにワ イヤ・プーリ経由で鍾による荷重を加えてェンドェフェク タに倒れモーメントを印加した .

5.3.2 試験結果 加えた倒れモーメントでは, 把持して いる取っ手の浮きは生じず，剛に把持できていることか確 認できた . 印加モーメントに対するモーメントアームの変 位の角度換算值を第 18 図にプロットして示す . 除荷時の戻 りにはスティックスリップを生じているが指の変形によっ て嵌合部に摺動を生じるためと考えられる. 要求性能の $50 \mathrm{Nm}$ でも問題なく保持できていることが確認でき，岡性

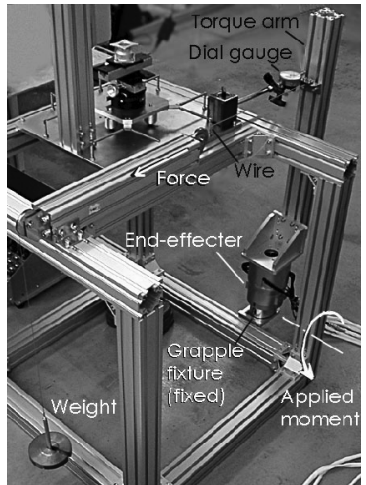

第 17 図＼cjkstart保持性試験のコンフィギュレーション

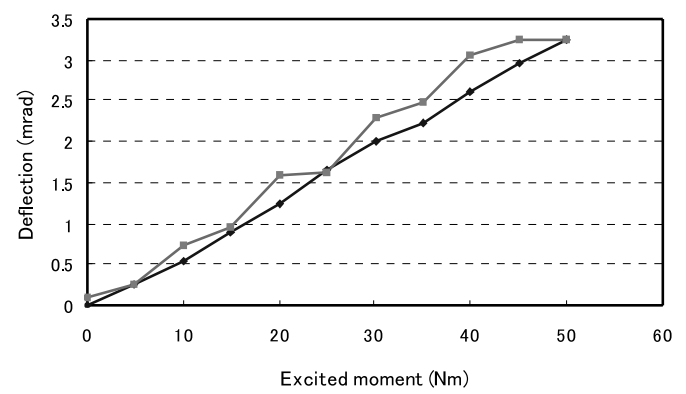

第18 図 保持性試験結果 (モーメントアーム変位)
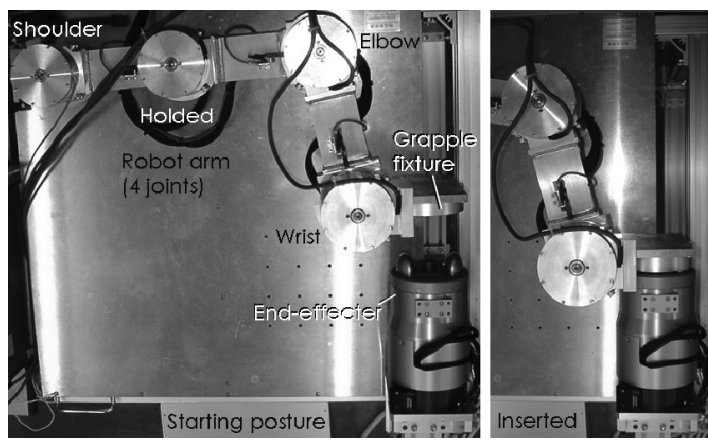

第 19 図 力覚制御挿入試験コンフィギュレーション

值は $1.54 \times 10^{4} \mathrm{Nm} / \mathrm{rad}$ で, クリップ式把持方式の高い耐 モーメント保持性能が確認できた .

\section{4 力覚制御挿入試験}

5.4.1 試験方法 2 次元動作ができる水平多関節アーム の手先部に大取っ手を取り付け，固定したエンドエフェク タへの挿入動作試験を実施した .試験装置の構成を第 19 图 に示す . ロボットアームの可搬重量制限のため，取っ手と エンドェフェクタを逆配置としたが，アーム動作による挿 入性の確認としては問題ないと考えられる．ロボットアー ムは，4関節の冗長自由度アームであるが，第 2 関節を常に 角度保持制御して，3 関節アームとして使用した . 試験での 挿入の横方向の初期位置ずれは $5 \mathrm{~mm}$, 挿入速度は $5 \mathrm{~mm} /$ 秒に設定した .

5.4.2 制御方式 センサとアクチュエータのコロケーショ ンにより，高い応答性の力覚制御動作を得るため，ロボッ トアームの関節トルクセンサ情報をフィードバックして関 
節単位の仮想インピーダンス制御13) を行った .アーム先端 に設定したい仮想岡性 $\boldsymbol{k}_{\mathrm{TIP}}$ から関節単位の捻り剛性 $\boldsymbol{k}_{\mathrm{JNT}}$ への変換は次式で行った .

$$
\boldsymbol{k}_{\mathrm{JNT}}=\boldsymbol{J}^{\mathrm{T}} \boldsymbol{k}_{\mathrm{TIP}} \boldsymbol{J}
$$

ここで, $\boldsymbol{J}$ は関節系からアーム先端系へのヤコビ行列であ る. 手首関節の仮想捻り岡性は目標とする先端の回転岡性 と同等のレベルに設定し，肩・肘の 2 関節は先端の並進剛 性から式 (8)により算出した捻り剛性に設定した . アーム の各関節の角度制御目標 $\theta_{\mathrm{REF} i}$ は次の式で求めた。

$$
\begin{aligned}
& \theta_{\mathrm{D} i}=\frac{1}{I_{i}} \int_{t_{0}}^{t} \int_{t_{i}}\left(\tau_{i}-\boldsymbol{c}_{i} \dot{\theta}_{i}-\boldsymbol{k}_{\mathrm{JNT} i} \theta_{i}\right) \mathrm{d} t^{\prime} \mathrm{d} t \\
& \theta_{\mathrm{REF} i}=\theta_{\mathrm{COM} i}-\theta_{\mathrm{D} i}
\end{aligned}
$$

ここで， $\quad I_{i}:$ 仮想慣性モーメント

$\tau_{i}:$ 関節トルク (トルクセンサ検出值)

$c_{i}:$ 仮想粘性係数

$\dot{\theta}_{i}:$ 関節の回転速度

$\theta_{i}:$ 関節の角度

$\theta_{\mathrm{COM} i}:$ 関節への角度指令值

試験では, 大取っ手の前面中央に仮想コンプライアンス

中心を設定し，次の仮想インピーダンスを使用した .

・仮想岡性 : $5000 \mathrm{~N} / \mathrm{m}, 5 \mathrm{Nm}$

·仮想粘性 : $475 \mathrm{Ns} / \mathrm{m}, 0.5 \mathrm{Nms}$

・仮想質量/慣性 : $10 \mathrm{~kg}, 0.1 \mathrm{kgm}^{2}$

また，嵌合位置に対する目標食い込み量は $40 \mathrm{~mm}$ に設定し た、なお，位置制御には関節モータ軸のロータリエンコー 㕛情報を用いた，また，位置・仮想インピーダンスの制御

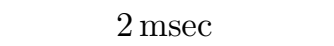

5.4 .3 試験結果 アーム動作によって，正常に挿入が行 えた . 挿入後の嵌合完了位置までの平均未達量は約 $0.8 \mathrm{~mm}$ であった . 挿入動作の履歴 (横方向位置 $X$, 横方向力 $F x$, 押し付け力 Fy) を第 20 図に示す.動作開始後，約 10 秒で 接触を生じ，滑らかなガイドによって挿入が行われ，約 16 秒の時点で挿入が完了した . 完了時の押し付け力は, 約 $9 \mathrm{~N}$ であった . (弚の後も仮想食い込み量の増加により押し付け 力は増加している）これにより，ガイド構造および取っ手 の形状は想定している制御方式である関節仮想インピーダ ンス制御に適合して滑らかにガイド・挿入ができることを 確認できた .

\section{6.おわりに}

軌道上での構造物組立用の宇宙ロボットのエンドェフェ クタを検討し，従来のエンドェフェクタ機構の適用におい て, 挿入性，保持耐性，取っ手の軽量化を課題として抽出 した .この課題に対して, 球面形状のガイド構造により良 好な挿入性を有し，新規のクリップ式把持方式により耐荷 重性および岡性の高い把持ができるエンドエフェクタ機構 方式とこれに対応した軽量の取っ手を新規に考案した . 乥 して , これらの機構の試作およひ試験により挿入性，保持
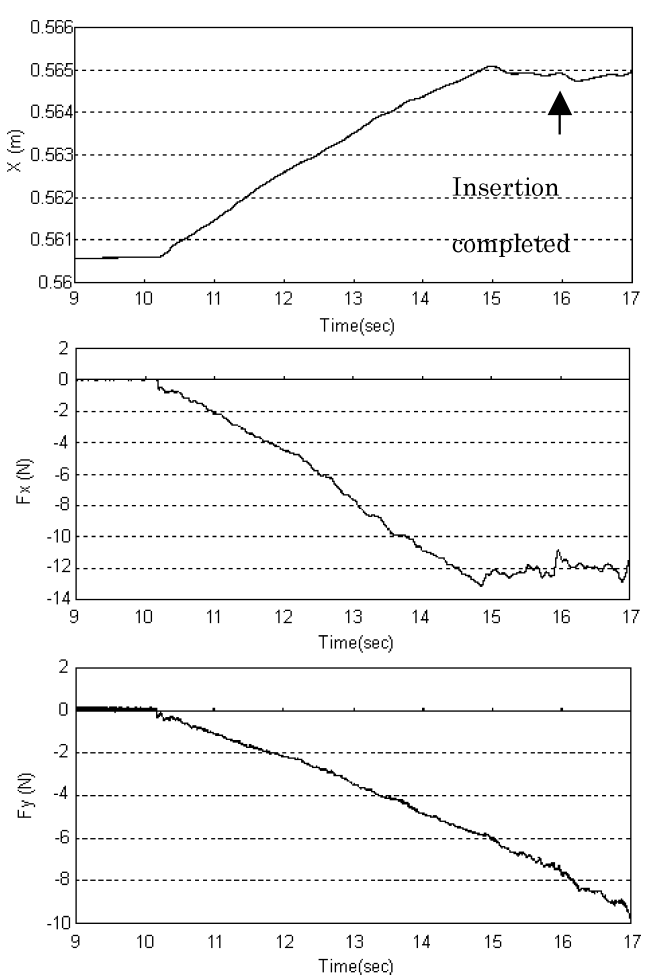

第 20 図 力覚制御挿入試験結果 (位置, 発生力履歴)

性などにおいて必要な性能が得られることを確認した . ま た，取っ手については，例えばETS-VII ロボット用取っ手 と比較して約 $1 / 10$ に軽量化ができた .さらに 2 次元ロボッ トアームを用いて軌道上での適用を想定している関節仮想 インピーダンス制御方式により良好にエンドェフェクタの 挿入動作が行えることを確認した .

エンドェフェクタの検討および試作に当たっては, 各種 の宇宙ロボットテストベッド用の試作を通じて , 若林靖史 氏, 稲場典康氏, 町田和雄先生, 上野浩史氏, 長谷川昭彦 氏に有益な議論，ご助言を戴いた、末筆ながら，深く感謝 の意を表します．

\section{参 考 文 献}

1) Nishida, S., Kawashima, N. and Okamura, R.: Onboard Assembling of Large Space Telescope by Space Robot, Tsukuba, Space Factory on ISS Workshop, Universal Academy Press, ISSN1345-7810, 1999.

2) 西田信一郎, 岡村 良, 我崎俊一, 高橋義幸, 半田利弘 : 宇宙口 ボットによる軌道上望遠鏡組立, 第 43 回宇宙科学技術連合講演 会, 1999.

3) Nishida, S. and Yoshikawa, T.: Onboard Assembling of Large Space Structure by Torque Controlled Space Robot, SPIE S\&S, 2003.

4) Nishida, S. and Yoshikawa, T.: Large Reflector Assembly in Orbit by a Mobile Space Robot, ISR2004, 2004.

5) Nagatomo, M., Mitome, T., Omote, T., Ezawa, N. and Kasuga, K.: Outline of Manipulator Flight Demonstration (MFD) Robot Arm, i-SAIRAS '97, 1997, pp. 195-200.

6) 小田光茂, 西田信一郎, 林 正人, 菅野崇, 稲場典康, 高野 裕, 稲垣哲也 : 技術試験衛星 VII 型ロボット実験系の開発，第 42 回宇宙科学技術連合講演会, 1998, pp. 29-34.

7）小田光茂，稲垣哲哉，赤塚宏一，小笠原肇，菅野明宏 : きく 7 号 
搭載ツール機構部の軌道上初期確認, 第 42 回宇宙科学技術連合 講演会 , 1998, pp. 88-94.

8) 西田信一郎, 岡村 良: 次世代ロボット用エンドェフェクタの試 作，第 42 回宇宙科学技術連合講演会，1998.

9) Nishida, S., Takegai, T., Ohi, Y., Machida, K., Toda, Y. and Iwata, T.: Prototype of an End-Effecter for a Space Inspection Robot, Advanced Robotics, 15 (2001), pp. 279-285.

10) 西田信一郎, 上野浩史, 松本秀一, 西槙健司: 軌道上組立構造要 素，第 45 回宇宙科学技術連合講演会，2001.

11) 松本康司，鈴木峰夫，川邑正広：種々の MoS2 焼成膜の高温真 空下でのトライボロジー特性, 第 45 回宇宙科学技術連合講演会
01-2F 16,2001

12) 西田信一郎, 林 正人, 小田光茂: 技術試験衛星 VII 型ロボット への力覚制御の適用, 日本機械学会論文誌 C 編 , 69 (2003), pp. 187-194.

13）西田信一郎, 吉川恒夫 : 宇宙用アクティブリンプロボット関節の 開発，日本航空宇宙学会論文集，52 (2004), pp. 393-401.

14）西田信一郎, 吉川恒夫 : 宇宙ロボット用トルクセンサ内蔵関節の 試作，第 20 回日本ロボット学会学術講演会予稿集，2002.

15) 小田光茂, 稲垣哲哉, 秋葉 宏, 上野真司：ETS-VII 搭載実験 用軌道上交換ユニットの開発及び運用結果の概要，第 42 回宇宙 科学技術連合講演会, 1998 . 